UDC $621.313 .32: 621.316 .729$ 621.311 .1

\title{
電力系統における同期機の非同期運転 および再同期現象
}

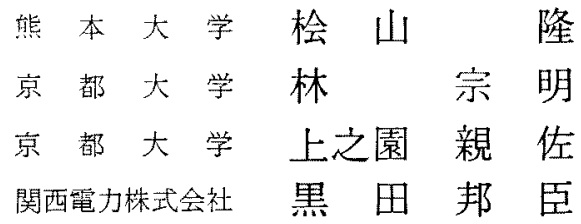

\section{1. まえがき}

現在，電力系統の運用にあたり柔統事故，この他の 原因に上り同期機が椸調するに至った場合，その同期 機は直ちに系統より分離され，脱調の原因を除去した 後系統に再併入する操作が行な的れている。しかし， 柔統加分分離された同期機の再併入には長時間を要す ることになり，大容量発電機を系統加ら長時間分離す ることは, 電力供給, 系統の経济的運用，信頼度など 心点加ら考えて好ましくない。三こで以前加ら，運転 中心発電機が脱調した場合, この発電機索統上り分 離することなく，同期化力の回復するまでの間，非同 期発電機として運転主ること加提案されてきている。 最近諸外国で行なわれた試験(1)の結果，ある状態のも とて限られた時間であれ柆非同期発電機として運枟で きることが示され，ソビエト，その他の国々に扰いて 実用化されている。

従来，この種の計算は一機無限大母線系統に求いて なされているが，本文においては有限の大きさの多機 電力采統任接続された一同期璣の非同期運車云，再同期

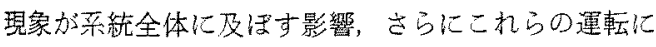
対するAVR，ガバナなどの制御系の与える効果など について，柔統をディジタル計算機に適した数式的モ

\footnotetext{
Computer Study of Asynchronous Operation and Resynchronization of an Alternator in a Power System. By T. HIYAMA Member (Institute of Electrical Engineering of Kumamoto University) M. HAYASHI, Member, C. UENOSONO, Member (Institute of Electrical Engineering of Kyoto University) \& $\mathrm{K}$ KURODA, Member (Kansai Electric Power Co., Ltd)

棯山 隆: 正虽，侦本大学工学部

萗明：正圆，京都大学工学部

上之圈親佐：正員，京都大学工学部

黑田 邦臣：正䝿，䦎西笔力株式会社
}

デル(2)であらわすことにより検討するものである。す なわ占，座摽変換に上り采統の諸变数をこれに対応す る同期機のP Park 変数にてあらわし，全采統の大信号 動作をあらわす系統方程式を $p \boldsymbol{x}=\boldsymbol{f}(\boldsymbol{x})$ なる形で求 $め$ ，乙の方程式を Runge-Kutta-Gill 法にて解くこと により，上記の諸運転状態における系統の動作を調べ る。実際の計算にあたっては，多機系綍のモデルとし て簡単な三機系統を用いる。さらに脱調した同期機が 再同期するために必要な条件についても，一機無限大 母線采統を対象とした位相面解析により求好ている。

\section{2. 系統の記述}

系統の大信号動作を表わす式は二つの座標采を基璴 として得られる。すなわち，各同期機はえれぞれの回 転子に固定された座標采に関して Park の变数をもっ て表わす。一方，送電系統および負荷は常に同期速度 $\omega_{0}=\left(2 \pi f_{0}\right)$ にて回転する共通基準座標軸に関する変 数にて表わし，同期譏の接続された各母線において， 二つの座標系で表わされた各变数走座標变換 ${ }^{(2)}$ により に関保つける。

$\langle 2 \cdot 1\rangle$ 座標变換 いま $\boldsymbol{W}_{d j}, \boldsymbol{W}_{D j}$ をそれそれれ $j$ 母線に招ける第 $j$ 同期機の回転座標系にて表わした同 期機の变数抢よび共通基淮座栖采にて表わした同期機 の变数とする。本文では全系統は対称であると仮定し 零相成分は省略してあるので， $\boldsymbol{W}_{d j}, \boldsymbol{W}_{D j}$ はこ机ぞ机 二次の列ベクトルとなり，両者の間には次の関保がな りたつ。(第1图参照)

$$
\boldsymbol{W}_{d j}=P\left(\delta_{j}\right) \boldsymbol{W}_{D j}, \quad \boldsymbol{W}_{D j}=P^{-1}\left(\delta_{j}\right) \boldsymbol{W}_{d}
$$

ただし， $\delta ; は$ は第 $j$ 同期機の回転子の共通基準座標軸か 


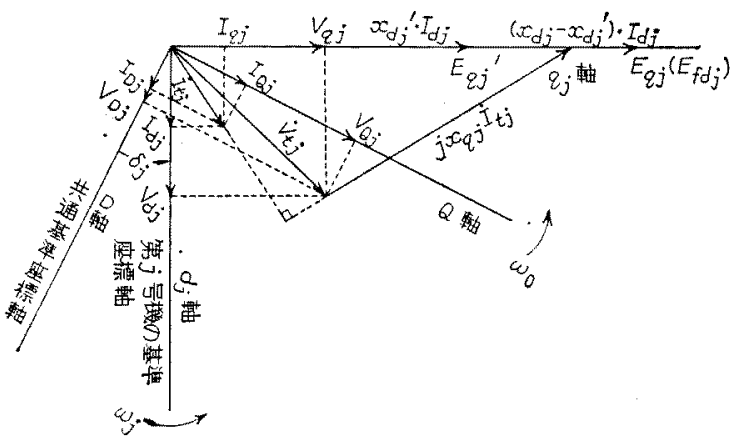

第 1 図 二つの座標軸とそ扎らの相互関係および 系統ベクトル図

Fig. 1. Phaser relation between two reference frames and vector diagram of system.

らの相差角を表わし， $P\left(\delta_{j}\right), P^{-1}\left(\delta_{j}\right)$ はそれでれ变換 行列およひその逆行列である。(付録 1 参照)

ここで相差角 $\delta$ ；は次のように表わされる。

$\delta_{j}=\left(\omega_{j}-\omega_{0}\right) t+\delta_{j 0}=\Delta \omega_{j} t+\delta_{j 0}$

ただし， $\delta_{j 0}, \omega_{0}$ ：それぞれ定常時の相苽角お

よび角速度， $\omega_{f}$ : 第 $j$ 同期機の角速度

〈2.2〉送電系統の表式 送電采統扰よび負荷は 共通基準座標軸に関して，電圧および電流の関係にて 表わされる。ここで同期機の接続されていない母線は すべて消去され，求めようとする回路方程式のなか加 組み入れられる心゙き母線だけを残している。いま $\boldsymbol{I}_{D j}$, $\boldsymbol{V}_{D j}$ をこれぞれ，第 $j$ 同期機の接続された母線に゙打け る電流ならこ゚に電纴とすれば雨者の間には次の関係が なりたつ。

$$
\boldsymbol{I}_{D j}=\sum_{k=1}^{n} \boldsymbol{Y}_{j k} \boldsymbol{V}_{D k}(j=1 \sim n)
$$

これに前述の座標变換を施し，各同期機の基準座標 に関する式に変換すれば次のようになる。

$$
\boldsymbol{I}_{d j}=\sum_{k=1}^{n} \boldsymbol{Y}_{j k}{ }^{\prime} \boldsymbol{V}_{d k}(j=1 \sim n)
$$

ただし

$$
\begin{aligned}
& \boldsymbol{I}_{D j}=\left[I_{D j}, I_{Q j}\right]^{T}, \quad \boldsymbol{V}_{D j}=\left[V_{D j}, V_{Q j}\right]^{T} \\
& \boldsymbol{I}_{d j}=\left[I_{d j}, I_{q j}\right]^{T}, \quad \boldsymbol{V}_{d j}=\left[V_{d j}, V_{q j}\right]^{T} \\
& \boldsymbol{Y}_{j k}=\left[\begin{array}{cc}
G_{j k}, & -B_{j k} \\
B_{j k}, & G_{j k}
\end{array}\right], \quad \boldsymbol{Y}_{j k}=P\left(\delta_{j}\right) \boldsymbol{Y}_{j k} P^{-1}\left(\delta_{k}\right)
\end{aligned}
$$

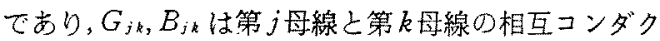
タンスおよびサセプタンスであり， $G_{j}, B_{j ;}$ は第 $j$ 母 線の自己コンダクタンスおよびサセプタンスである。

本文では送電菒統の周波数变化に上る送電線および 負荷の抵抗，インダクタンスの变化は少ないものと仮 定し， $\boldsymbol{Y}_{j k}$ を定数行列として报っている。

〈2.3〉 系統方程式系統方程式は，同期機の電

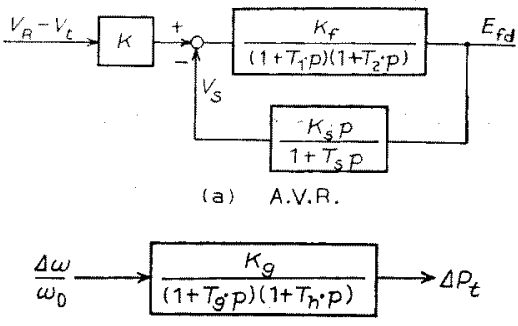

(b) ガバナ

第 2 図 発電機のAVR とガバナの構成線図

Fig. 2. Block diagrams of widely used continuously acting voltage regulator and governor.

気的特性，機械的特性および同期機化付属する制 御系（AVR，ガバナ）の動作を記述することにより 得られる。ここでは，Kimbark 氏によってまよめら れた同期機のモデル ${ }^{(3)}$ を採用し，過渡内部誘起電生の 時間変化を考虑し，運動方程式における同期機の電気 的出力は，同期出力と非同期出力とに分けて考えてい る。(付録 2 参照)

AVR,ガバナについては第 2 四のモデルを用い，そ れぞれの動作は以下のようになる。

$$
\begin{aligned}
E_{f d j}= & \frac{K_{f j}}{\left(1+T_{1 j} p\right)\left(1+T_{2 j} p\right)}\left\{K _ { j } \left(V_{R j}\right.\right. \\
& \left.\left.-V_{t j}\right)-V_{s j}\right\} \quad \ldots \ldots \ldots \ldots \ldots \ldots \ldots \ldots \ldots \ldots \ldots \ldots \\
V_{s j}= & \frac{K_{s j} p}{1+T_{s j} p} E_{f d j} \quad \ldots \ldots \ldots \ldots \ldots \\
\Delta P_{i j}= & \frac{\Delta K_{g j}}{\left(1+T_{g j} p\right)\left(1+T_{h j} p\right)} \frac{\Delta \omega_{j}}{\omega_{0}} \ldots \ldots \\
た た ゙ し, & \\
V_{R j}= & E_{f d j 0} / K_{j} K_{f j}+V_{t j 0} \\
V_{t j 0}= & V \overline{V_{d j 0}^{2}+V_{q j 0}{ }^{2}}
\end{aligned}
$$

であり添字 0 は定常時における值を，添字 $j$ 梳第 $j$ 同 期機を示す。また AVR 動作の飽和はAVRの出力を 制限することにより考慮している。すなおち

$$
E_{f d j \min } \leq E_{f d j} \leq E_{f d j \max }
$$

全系統の動作は，上記 (5) （7) 式，(付 1$) \sim($ 付 5 )式扰じ (4)式を用いて，非線形連立一階微分方 程式にて次のように表わされる。

$$
p \boldsymbol{x}=\boldsymbol{f}(\boldsymbol{x})
$$

ただし，状態変数ベクトル $\boldsymbol{x}$ は

$$
\begin{aligned}
\boldsymbol{x}= & {\left[\Delta \delta_{1}, \Delta \omega_{1}, \Delta E_{q 1}{ }^{\prime}, \Delta E_{d 1}{ }^{\prime}, \Delta E_{f d 1},\right.} \\
& p \Delta E_{f d 1}, V_{s 1}, \Delta P_{t 1}, p \Delta P_{t 1}, \cdots \cdots, \\
& \left.V_{s n}, \Delta P_{t n}, p \Delta P_{t n}\right]^{T}
\end{aligned}
$$

本文では(8)式学 Runge-Kutta-Gill 法にて解くこ とにより系統の諸特性を調べた。 
第 1 表 系統定数

Table 1. System constants.

\begin{tabular}{|c|c|c|c|c|c|c|c|c|c|}
\hline & $x_{d}$ & $x d^{\prime}$ & $x d^{\prime \prime}$ & $x_{q}, x_{q^{\prime}}$ & $x_{q}^{\prime \prime}$ & $T_{d^{\prime}}$ & $J$ & & $K a$ \\
\hline 第 1，2号機 & 1.15 p.u & 037 p.u. & 0.24 p.u. & 0.75 p.u. & 0.34 p.u. & 1.3 & 5.6 & s & 25.0 \\
\hline \multirow[t]{2}{*}{ 學 3 量棫 } & $0.115 \mathrm{p} . u$ & 0037 p.u. & $0.024 \mathrm{p.u}$ & 0.075 p.u. & 0.034 p.u. & $1.3 \mathrm{~s}$ & 56.0 & s & 95.0 \\
\hline & $T_{d^{*}}, T_{q}$ & $T_{\theta}$ & $T_{h}$ & $K$ & $K_{f}$ & $K_{s}$ & $T_{1}, T$ & & $T s$ \\
\hline 第 $1,2,3$ 塄機 & $0.030 \mathrm{~s}$ & $0.3 \mathrm{~s}$ & $0.3 \mathrm{~s}$ & 1.0 & 5.0 & 0.007 & 0.2 & $s$ & $0.3 \mathrm{~s}$ \\
\hline$Z_{1}$ & $0.0+j 0.4 \mathrm{p} . \mathrm{u}$ & $Z_{2}$ & $0.0+j 0.1$ p.u. & $z_{3}$ & \multicolumn{2}{|c|}{$0.0+j 0.1$ p. } & $Z_{1 \mathrm{~s}}$ & \multicolumn{2}{|c|}{$0.0+j 0.1$ p.u. } \\
\hline$Z_{12}$ & $0.0+j 0.3 \mathrm{pu}$ & $Z_{L_{1}}$ & $0.3+j 0.1 \mathrm{p} . \mathrm{u}$ & $z_{L_{2}}$ & \multicolumn{2}{|c|}{$0.1+j 0.02 \mathrm{p.u}$} & & & \\
\hline
\end{tabular}

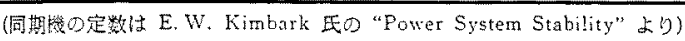

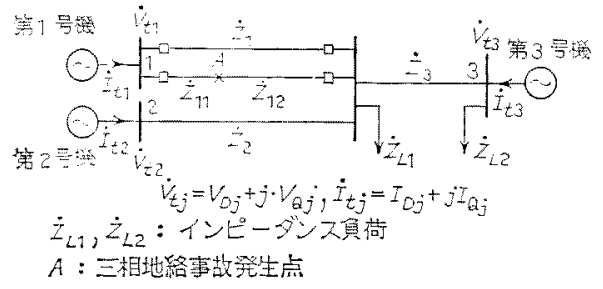

第 3 図 モデル三機采統

Fig. 3. Model of 3 machine system.

\section{〈2.4〉モデル系統および初期条件 多譏電力系} 統のモデルとして，第 3 四に示す三機系統を用いた。 このモデル系統にて第 3 号機は使宜的に大梘模哥統を

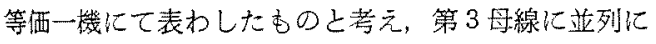
接続された 10 機程度の同期機を表わすものとする。 さらにこの大規模系新で消費される電力は第 3 母 線に並列に接続されたインピーダンス貝荷の消霣電力 と等価であるとしている。とのようなモデル番統によ り第 1 号機の非同期選転むよび再同期が系統に及ぼす 影響は，てれらの運転状態における第 2 号機の動搯を 調べることによりわかる。乐統定数仙第 1 表に示す。 系統方程式を解く前化必要亡なる初期条件好第 2 表に 示す。乙れは采緇の湖流計算を行ない第 1 図のベクト ル図により求めたものであり，各同期機のモデルとし

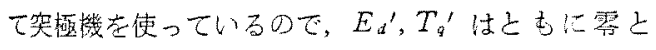

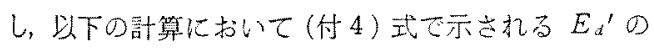
持間变化考考慮していない。

\section{3. 同期機の非同期運転 $(4)$}

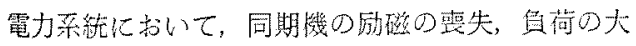

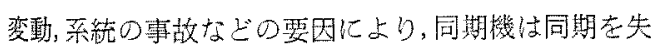
うことがあり，ての脱調した同期被を系統より分離し

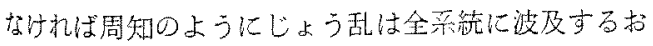
それがある。しかし，分雅してもをれが長時間儿わた る場合には采統ししての供給力に不足在生じやす。 最近の発電機の大容量化に判，乙の㑯向はますます
第 2 表 初期午件 Table 2. Initial conditions.

\begin{tabular}{c|c|c|c}
\hline & 第1 号機 & 符 2号嵝 & 第3 号機 \\
\hline$P$ & 1.000 & 1.000 & 9.767 \\
\hline$Q$ & 0.400 & 0.579 & 2.154 \\
\hline$V_{t}$ & 1.000 & 0.994 & 0.973 \\
\hline$V_{D}$ & 0.9899 & 0.9937 & 0.9732 \\
\hline$V_{Q}$ & 0.1416 & 0.0348 & 0.0000 \\
\hline$I_{t}$ & 1.0770 & 1.1619 & 10.2766 \\
\hline$I_{D}$ & 1.0465 & 1.0254 & 10.0354 \\
\hline$I_{Q}$ & -0.2544 & -0.5463 & -2.2132 \\
\hline$E_{f d}$ & 1.8392 & 2.0108 & 1.6605 \\
\hline$E_{q^{\prime}}$ & 1.1793 & 1.2435 & 1.0850 \\
\hline$\delta_{0}$ & -0.9055 & -1.0506 & -0.9870 \\
\hline$\delta_{12}$ & 0.1451 & & \\
\hline$\delta_{13}$ & 0.0815 & & \\
\hline$\delta_{23}$ & & -0.0636 & \\
\hline
\end{tabular}

強くなっている。したがってなんらかの原因により 同期機が脱調した場含，乙の励磁を语当に操作して同 期化力口回復するまての間，非同期発電㙨として彔統 に電力を供給しつつ連軽し，比咬的短時間の㣪に再同 期化させることが若えられる。民こで，ての同期機の 非同期運檕が系統に刘してどのような影䇾を及ぼすか をモデル系絖について調へてみた。

〈3・1〉定常非同期運転同期後は以下に示す檑 々の所礔回路の状態に詨して，定常非同期運転にはい る。（1）励磁回路至短絡した場合，(2) 矿磁回路老放

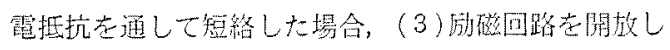
た場合，(4)励酳が等万埸合，

(1)〜（4）の各暏合と夺タービン出力 $P_{t}-J P_{t}$ と

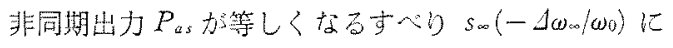

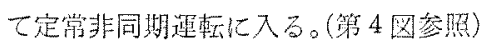

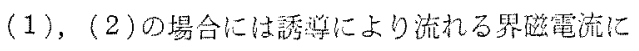

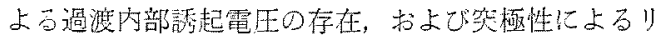




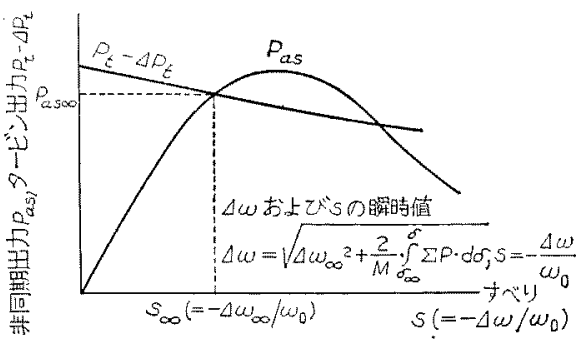

第 4 図 スリップに対する発霓機の非同期 出力とタービン出力

Fig. 4. Asynchronous power of generator and turbine power vs slip.

ラクランス出力の存在により，（3）の場合には笑極性 によるリラクタンス出力の存在により，(4)の場合に は同期出力の存在により，各場合と屯すべり 5 は $s_{\infty}$ を平均值として脈動しさらに系統の諸变数を徯述のよ うに脈動する。(4)心場合，三の脈動の振幅は同期出 力の波高値に上り決定され，同期機の再同期のための 条件を決定するにあたっては，このすべりの脈勳搌愊 が重要な意味をもってくる。

\section{〈3.2〉同期機の非同期運転が采統に及ぼす影響}

モデル系統にて第 1 号譏の朸磁回路を短絡すること により非同期発電機として運転した場合の系統の動摇 を調ベてみた。この非同期運枟中の各同期機の端子電 Eの変化は第 5 図に示される。この図かる明らかなよ うに第 1 号機の端子電生は定常時の 50 60\% K，他 の同期機の端子電王は定常時の 90\% 程度に低下寸る。 しかしながら第 5 図の破線に示されるように第 1 号機 以外の同期機の端子電田はそれらの同期機のAVRに より定常值まで回復させることが可能である。さた， 第 5 图に示方無效電力の変化により，第 1 号機はこの

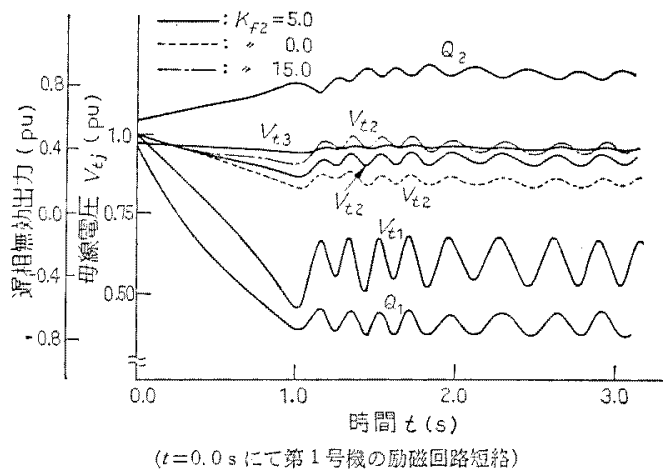

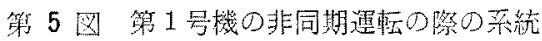
の母線電压，扣上び遲相無效出力口変化

Fig. 5. Changes of bus voltages and reactive powers during asynchronous operation of machine No. 1.

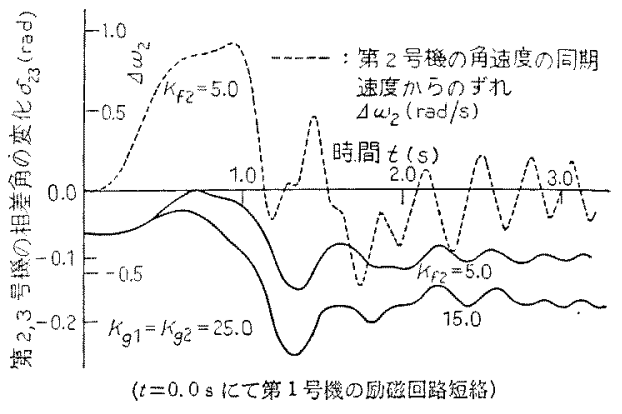

第 6 図 第 1 号機の非同期算転中の第 2,3 罗譏間の相差弯の变化

Fig. 6. Relative motion between machine No. 2 and No. 3 during asynchronous operation of machine No. 1.

非同期運転中，暒相の無效電力を消費することがわか る。この第 1 号機の無効電力の消費が，第 5 図に示さ 机るような系統全体の電圧の低下を引き起こすといえ る。また第 6 图化相差角の変化に示されるように，こ の非同期運転中第 2 ，第 3 号機は己机ぞ机はと九ど同 期を保って動いている。したがって，第 1 号機の非同 期運転が第 2 ，第 3 号機に対してそれほど大きな影艟 を及ほさないといえる。

また以上の図より，すべての采統量，すなわ占相差 角，すべり，母線電圧，母線電流，有効，無効出力な どは非同期運転の期間中脈動している。これは先記の ように，誘導による界磁電流の存在，突極性によるり ラクタンス出力の存在などに起因している。

\section{4. 同期機の再同期現象}

同期機が脱調した場合，従来の上うに系統加らの分 雜，再件入乞いう過程古通らずに以下に示すような操 作を行なえば，短時間にこの同期機を再同期化させる ことが可能である。すなおち，(1)脱調した同期機の 励磁回路を短絡あるいは開放するこ上により，この同 期機党非同期発電機として運軽する。(2)ガバナによ りこの同期機の軸トルクの調整を行なう，(3)尉䃟電 流古再び供給して，この同期機を再同期化させる。

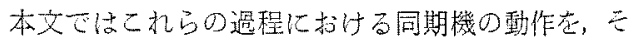
の再同期琴象と呼ふことにする。

$\langle 4 \cdot 1\rangle$ 再同期の過程 エデル采統に㕲ける第1 号機の代表的な再同期の過程老節 7 図( a ) 〜 ( c) 亿示 す。これらの四において，A1〜 $A_{5}$ は次の各状態を示 している。

$A_{1}$ ：モデル系統の $A$ 点にて三相地絡事故の発生 $(t$ $=0.0 \mathrm{~s}), A_{2}$ : 故障回線のしゃ断 $(t=0.30 \mathrm{~s}), A_{3}$ : 故 障回線の再閉路 $(t=0.40 \mathrm{~s}), A_{4}$ : 第 1 号機脱摆，䛿磁 


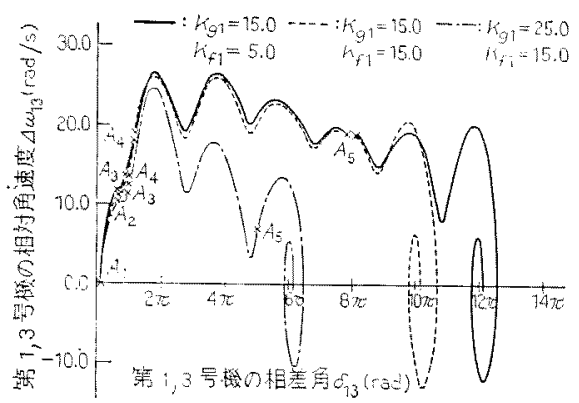

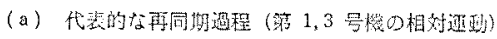
(a) Typical resynchronization process

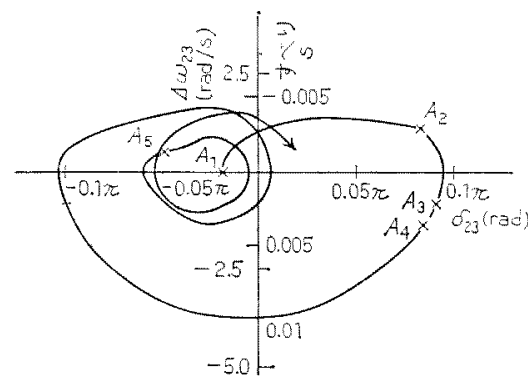

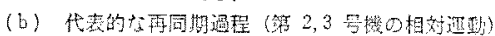
(b) Typical resynchronization process

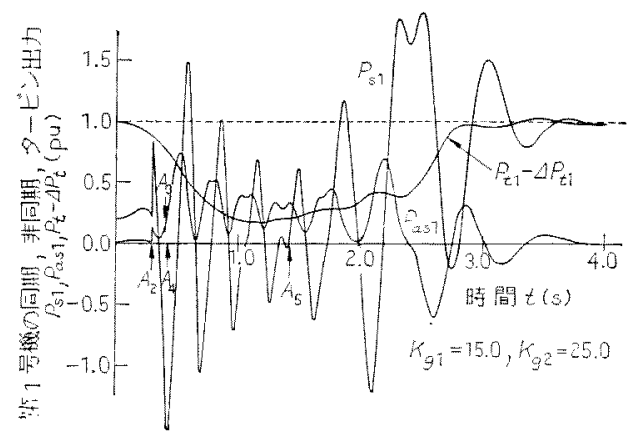

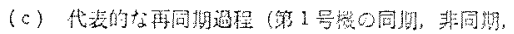
タービン出力の時間变化

(c) Typical resynchronization process

符 7 図

Fig. 7.

回路の短䅂 $(t=0.42 \mathrm{~s}), A_{5}$ ：励路再投入 $(t=1.42 \mathrm{~s})$, ただし $A_{3}$ にて事故枋消減しているものとする。

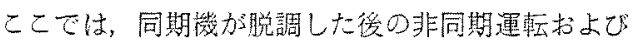
それに続く再同期現象の解析に重点を执いているため 故障回線のしゃ断までの㭙間在くとり，第 1 号機が

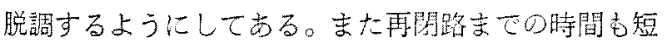
汃とっている。

第 7 四(c)に示さ机るように，第1号機の同期出力 はこれらの過程を速してかなり路採している。しかし

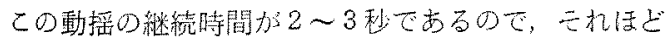
問題はない上劣はら机る。また，同因(b)に心第 2 号
機，第了号機の相対的な動作を示してある。この图か

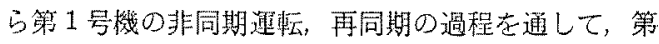
2 号幽，第 3 号機がほぼ同期を保って動作しているこ しが確認できる。したがって，同期機の再同期睍象屯 先に述べた励磁回路の短絡に上る非同期運軽之同様に

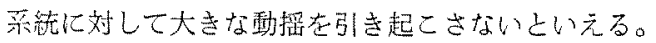

\section{$\langle 4 \cdot 2\rangle$ 糸統諸パラメータの効果}

くガバナの效果〉 非同期運䎐中，ガバナはタービン 入力を調整するしとにより，同期袎のすべり扰よひ出 力在調整する。ガバナ利得が大きくなるに雄って，非同 期䞨転中の平均す心りりは小ざくり，第 7 图(a)に示 さ机るようにガバナ利得が大きいほじ再同期させやす くなる。さらにガバナの陲作は采統の電気的特性に対 して直接影留索与えないので，同期機の再同期屍え る際には,ガバナの利得を增加させるこ上が望まれる。 $<$ AVR の効果> AVR の隞きは第7図(a)に示さ れるように再同期に対して效果がある。これは非同期

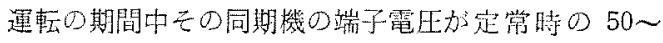
60\% に低下し，したがって，丽同期化させるたるに 励磁電流在ふたたざ供給したよきにAVRの動作によ

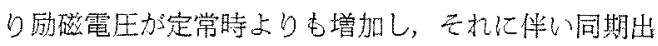
力の波高值屯定常時より增加することによる。したが って，AVR の動作により，励磁倛給上り再同期にい たるまでの時間は短縮できる。

厉磁回路㭙定数，惯性定数，外部りアクタンスの影 丝ここれらのパラメータの影暗については紙面のつ こう上，图在省格ずる。計算結果に上执ば励磁回路封定 数が小さいほよ゙再同期に要する時間は短縮できる。こ れは内部唀起電压が励磁投入得, 励磁回路時定数に往 って，にぼ指数閔数状に增加するこしより説明できる。

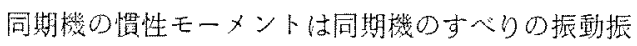
幅に閔係し，慣性定数が小さいはどその振幅は大きく

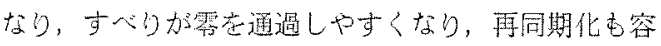

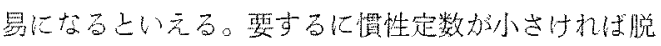
調しやすい代方りに而同期をしやすいことになる。

同じすハらりの值に刘して，外部リナクタンス（这電 線かよび变在器のリアクタンス）の大きな同期機ほよ゙ 气の平均非同期出力仙さくなり，したがって，同じ 運転状態においては外部りアタタンスの小さいによ゙非

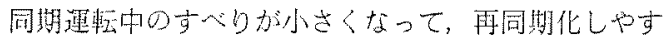
〈古。

\section{5. 再同期の条件}

前節の部算結果加ら明ら力なよう飞，比較的大きい

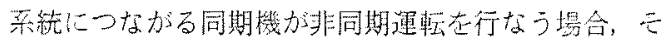

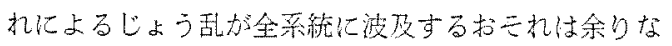


いと涄起てよい。したがって，ここでは一機無限大母 泉系統を考无，杂件を簡単化しその位相面解析により 司期機の再同期化のために必要となる条件について考 察する。

$\langle 5 \cdot 1\rangle$ 位相面方程式 同期機の再同期の過程は 欠の力程式で表わされる。(5)

$$
\begin{aligned}
M p^{2} \delta & +P_{d}(1-b \cos 2 \delta) p \delta \\
& +P_{m}\left(1-\varepsilon^{-t / T d^{\prime}}\right) \sin \delta+P_{r} \sin 2 \delta \\
& =P_{t}-\Delta P_{t} \ldots \ldots \ldots \ldots \ldots \ldots \ldots \ldots \ldots
\end{aligned}
$$

ガバナ動作の㭙間暹れを無視すれば $\Delta P$ は は

$$
\Delta P_{t}=K_{\vartheta} p \delta / \omega_{0}
$$

上なり，位相面方程式は次のようになる。

$$
\begin{aligned}
& d \Delta \omega / d \delta=\left(P_{t}-\left\{P_{d}(1-b \cos 2 \delta)\right.\right. \\
& \left.+K_{g} / \omega_{0}\right\} \Delta \omega-P_{m}\left(1-\varepsilon^{-t / T^{\prime} d^{\prime}}\right) \sin \delta \\
& \left.-P_{r} \sin 2 \delta\right] / M \Delta \omega \\
& \text { ただし， } \Delta \omega=p \delta
\end{aligned}
$$

上なる。

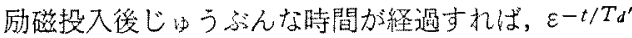
D項は 0 となるので(11)式は次のようになる。

$$
\begin{aligned}
d \Delta \omega / d \delta & =\left[P_{t}-\left\{P_{d}(1-b \cos 2 \delta)\right.\right. \\
& \left.+K_{\theta} / \omega_{0}\right\} \Delta \omega-P_{m} \sin \delta \\
& \left.-P_{r} \sin \delta\right] / M \Delta \omega \ldots \ldots \ldots .
\end{aligned}
$$

このとき，安定扔よび不安定特買点を与える方程式 は(9)式において $t \rightarrow \infty, p \delta=0, p^{2} \delta=0$ として

$$
P_{m} \sin \delta+P_{r} \sin 2 \delta=P_{\iota}
$$
となる。

〈5.2〉位相面トラジェクトリと再同期の条件

(12)式にて与えられる 位相面トラジエクトリは 第8国に示されるように 次の四つの形飞分類 ${ }^{(6)} \mathrm{d}$ 吅る。

(a) 平衡点加存在し ない場合奴なる初 期点を出然したトランジ

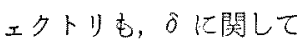
$2 \pi$ の周期在古つ定常曲 湶*収来する。この場 合比次の条件式方的り たつ。
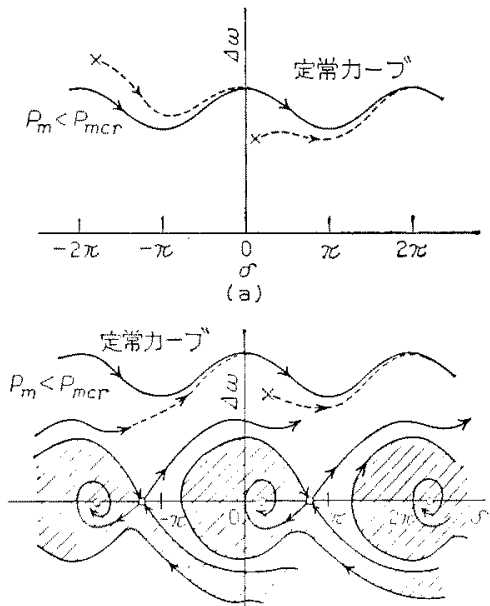

(b)

$$
\begin{aligned}
& P_{m} \sin \delta_{m}+P_{r} \sin 2 \delta_{m}<P_{t} \\
& \delta_{m}=\cos ^{-1}\left\{-\frac{1}{8}\left(\frac{P_{m}}{P_{r}}\right)+\sqrt{\left(\frac{1}{8}\right)^{2}\left(\frac{P_{m}}{P_{r}}\right)^{2} \frac{1}{2}}\right\}
\end{aligned}
$$

(b) 特異点と定常曲線力存在する場合

と場 合，四の斜線部に初期值をもつトラジェクトリは安定 特異点に収束し，その他の初期点を出発したトラジメ クトリは定常曲線汇収束する。

（c）定常曲線が存在しない場合ここ場合には いかなる初期点在出発したトラシェクトリも安定特巽 点に収束する。

(d) 定常曲線が不安定特暴点を結ふ调期 $2 \pi$ D曲 線となる場合この場合, 図の斜線部に初期值をもつ トラジェクトリは安定特異点に収束し，乙の他の初期 点出発したトラジェタトリは定常曲線に收束する。

しかし，この場合の定常曲線は不安定特異点を結心 周期 $2 \pi$ の曲線であり，不安定特異点はくら形点であ るから，じゅゔん長い間の後には安定特暴点へ収束 する可能性もでてくる。

同期機の再同期の条件は上記の (d)の北のトラジェ クトリにより与えられる。すなわち，周期 $2 \pi$ の定常 曲線の消減が再同期に必要な条件となる。そこで，不 安定特異点の近傍に初期点莡与光，(12)式の位相面方 程式を解き，トラジェクトリが次の不安定特異点を通 過するための条件を求める。

初期点《次の上うにあらわされる。

$$
\begin{aligned}
& \Delta \omega=(d \Delta \omega / d \delta)_{\delta=\delta_{2}} \Delta \delta \\
& \delta=\delta_{2}+\Delta \delta
\end{aligned}
$$
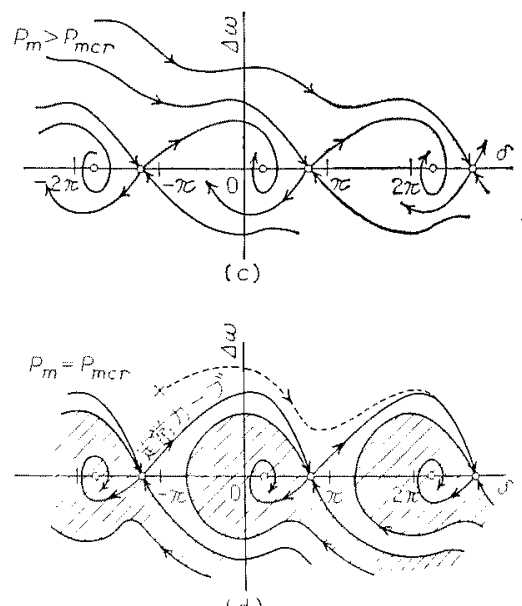

(d)

第 8 四笔打乐䟽の大振動に対する位相面トラジェクトリの分類

Fig. 8. Classification of phase plane trajectories on large oscillation of power system.

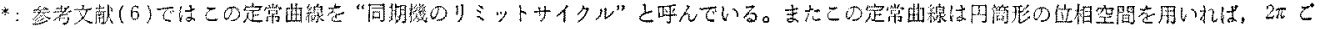

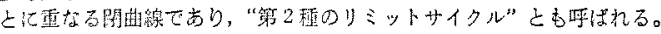




$$
\begin{aligned}
& (d \Delta \omega / d \delta)_{\delta=\delta} \\
& =\frac{1}{2}\left[-\frac{1}{M}\left\{P_{d}\left(1-b \cos 2 \delta_{2}\right)+K_{\theta} / \omega_{0}\right\}\right. \\
& +\sqrt{\left[-\frac{1}{M}\left\{P_{d}\left(1-b \cos 2 \delta_{2}\right)+K_{g} / \omega_{0}\right\}\right]^{2}} * \\
& \text { * }-4\left(P_{m} \cos \delta_{2}+2 P_{r} \cos \delta_{2}\right)
\end{aligned}
$$

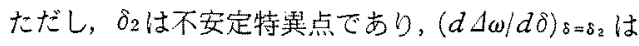
トラジェクトリが不安定特異点を出発するときのこう 配である。

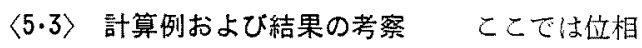
面方程式(12)を Runge-Kutta-Gill 法にて解き系統諸 パラメータの再同期に対する影響在考察する。

第 9 図 (a), (b) 代計算結果を示す。図中 $P_{m c r}$ は再 同期のために必要な同期化力の波高值 $\left(=E_{q}^{\prime} V /\left(x_{d^{\prime}}\right.\right.$ $\left.+x_{t}\right)$ を示す。

こ机らの図から明らかなように，同期機考再同期さ せることが, 不可能上なる平均すべりの最大值が存在 し (7), 第 9 図 (a)参照〕この最大值は, 励磁回路の頂 上電圧により決定さ机る同期出力の波高值により定ま る。したがって，同期㙨の再同期化をはかるにあた。 ては，非同期運転中の平均すべりをこの最大値以下に おさえる必要がある。また諸パラメータの影響につい ては，〈4・2〉節で述べたのと同様の効果が認められ た。さらに，(b)罒に示されるように同期機の制動係 数 $P_{d}$ 屯再同期に対して大きな影響をもつてとが示さ れる。同期機の突極性は紙面のつごう上，図は省略す るが，再同期に対してほとんど影響を与えない。ただ し，ここでは AVRの動作を考虙せず，同期機の内部 誘起電主 $E_{q}{ }^{\prime}$ は一定としている。

\section{6. むすび}

以上得られた結果をまとめると次の上うになる。

(1) 同期機の非同期運転中には, 種々の系統变数 たと元ば有効出力, 無効出力, 母線電圧, 母線電流な どが脈動をはじめる。また，非同期運枟中の同期機の 母線電圧は定常時の 50〜60\%に低下し,これに隣接す る他の同期機の母線電圧も定常時の $90 \%$ 程度に低下 する。しかし，比較的遠方の同期機の母線電压の低下は その同期機のAVR の動作により防ぐことができる。

(2) 多機電力系統における一同期機の非同機運転 は他の同期機の動作に一特にその同期に一ほ上んど影 響を与えない。すなわち，他の同期機はほぼ同期を保 って動作する。

（3）同期機の再同期住対してガバナの動作が効果

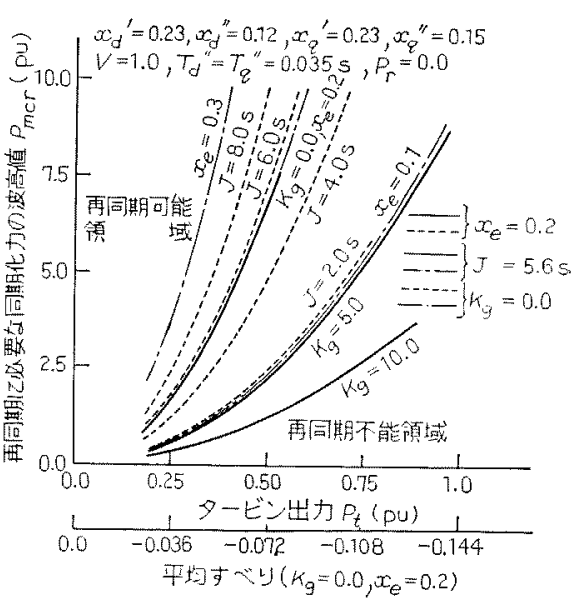

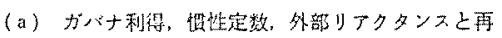

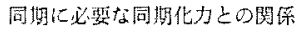

(a) Effects of governor gain, inertia constant, and external reactance on the magnitude of synchronous power required to resynchronize the machine.

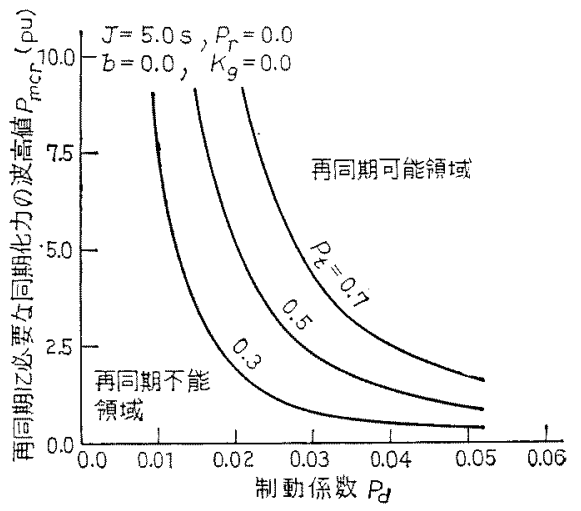

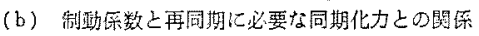

(b) Effect of damping caefficient on the magnitude of synchronous power required to resynchronize the machine.

第 9 図

Fig. 9.

的であり，またAVRの動作も効果がある。

（4）非同期運転中の平均すべりが同期機の再同期 を考える際に重要になってくる。すなわち，同期機を 再同期化させることが不可能となる平均すべりの最大 值が存在し，この最大值は励磁回路の頂上電化により 定まる同期出力の波高値により氿定される。

(昭和46年10月14日受付, 同47年 4 月24日再受付)

\section{文献}

(1) 挒苋结, T.H. Masson: Proc. Inst Elect. Engrs 1106 A, p. 357 (1959)

(2) K. Prabhashankar: EEE Trans. Power Apparatus Syst. PAS-87 No. 1, p. 73 (1968) 
(3) E. W. Kimbark. "Power system stability", Book, (1956) John Winly \& Sons

(4) V.A. Venikov: "Transient phenomena in electrical power system", Book, (1965) Pergamon Press

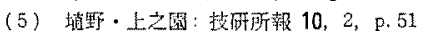

(6) 三浦, 化 : 雪学望 89,899 (炤 44-5)

(7) O.P. Malik: Proc. Inst. Elect. Engrs 113, No.12, p. 1977 (1966)

(S) R. N. Sudan: Proc. Inst. Elect. Engrs 79, Pt. 1, p. 1120 (1960)

(9) D.B. Mehta: I.E. E., Paper No.3160S, p. 61 (1960)

\section{付 録}

\section{1. 変換行列およびその逆行列}

$$
\begin{aligned}
& P\left(\delta_{j}\right)=\left[\begin{array}{cc}
\cos \delta_{j} & \sin \delta_{j} \\
-\sin \delta_{j} & \cos \delta_{j}
\end{array}\right] \\
& P^{-1}\left(\delta_{j}\right)=\left[\begin{array}{cc}
\cos \delta_{j} & -\sin \delta_{j} \\
\sin \delta_{j} & \cos \delta_{j}
\end{array}\right]
\end{aligned}
$$

\section{2. 同期機の表現 ${ }^{(3)(8)}$}

$$
\begin{aligned}
& p \delta_{j}=\Delta \omega_{j} \ldots \ldots \ldots \ldots \ldots \ldots \ldots \ldots \ldots \text { (付 } 1 \\
& p \Delta \omega_{j}=\left\{P_{i j}-\Delta P_{t j}-\left(P_{s j}+P_{a j j}\right)\right\} / M_{j}
\end{aligned}
$$

景磁回路の磁束变化

$$
\begin{aligned}
p E_{q j^{\prime}}= & \left\{E_{f d j}-E_{q j^{\prime}}\right. \\
& \left.\left.-\left(x_{d j}-x_{d j^{\prime}}\right) I_{d j}\right\} / T_{d j^{\prime}} \quad \ldots \text { (付 } 3\right) \\
p E_{d j^{\prime}}= & \left\{-E_{d j^{\prime}}+\left(x_{q j}-x_{q j^{\prime}}\right) I_{q j}\right\} / T_{q j^{\prime}}
\end{aligned}
$$

$$
\begin{aligned}
& \text { ただし， } \\
& P_{s j}=V_{d j} I_{d j}+V_{q j} I_{q j} \\
& P_{a s j}=\frac{1}{2} V_{t j}{ }^{2}\left\{\frac{x_{d j}-x_{d j^{\prime \prime}}}{x_{d j} x_{d j}^{\prime \prime}} \frac{\Delta \omega_{j} T_{d j}^{\prime \prime}}{1+\left(\Delta \omega_{j} T_{d j}^{\prime \prime}\right)^{2}}\right. \\
& \left.+\frac{x_{q j}{ }^{\prime}-x_{q j^{\prime \prime}}}{x_{q j} x_{q j^{\prime \prime}}} \frac{\Delta \omega_{j} T_{q j^{\prime \prime}}}{1+\left(\Delta \omega_{j} T_{q j^{\prime \prime}}\right)^{2}}\right\}^{(4)(9)}
\end{aligned}
$$

上式に㧈いて $P_{a s j}, P_{s j}$ はそれぞれ第 $j$ 同期機の非 司期出力，同期出力を表わし，P $P_{a s j}$ の右辺第一項は制 勘巻線仪よる非同期出力の直軸成分，第二項は横朝成 分を表加す。（付 3 )式に上り $E_{q}{ }^{\prime}$ の時間变化を考元 る場合には，Ps は同期出力ととも誘導により流れ る界磁電流汇より生じる界磁巻線の非同期出力を表わ t。

また，第 $j$ 同期機の母線電圧，母線電流打よび過渡 勺部誘起電壬との間には

$$
\boldsymbol{V}_{d j}=\boldsymbol{E}_{d j^{\prime}}+\boldsymbol{X}_{d j}{ }^{\prime} \boldsymbol{I}_{d j}
$$

口関係があり，この式上本文中の (4)式上り同期機方 呈式の中江含まれる, 系統の状龍変数以外の变数 $V_{d j}$, $7_{q j}, I_{d j}, I_{q j}$ は系統の状態变数 $\delta_{j}, E_{q j}{ }^{\prime}, E_{d j}{ }^{\prime}$ を用い こ, 次の行列方程式により決定される。 運動方程式

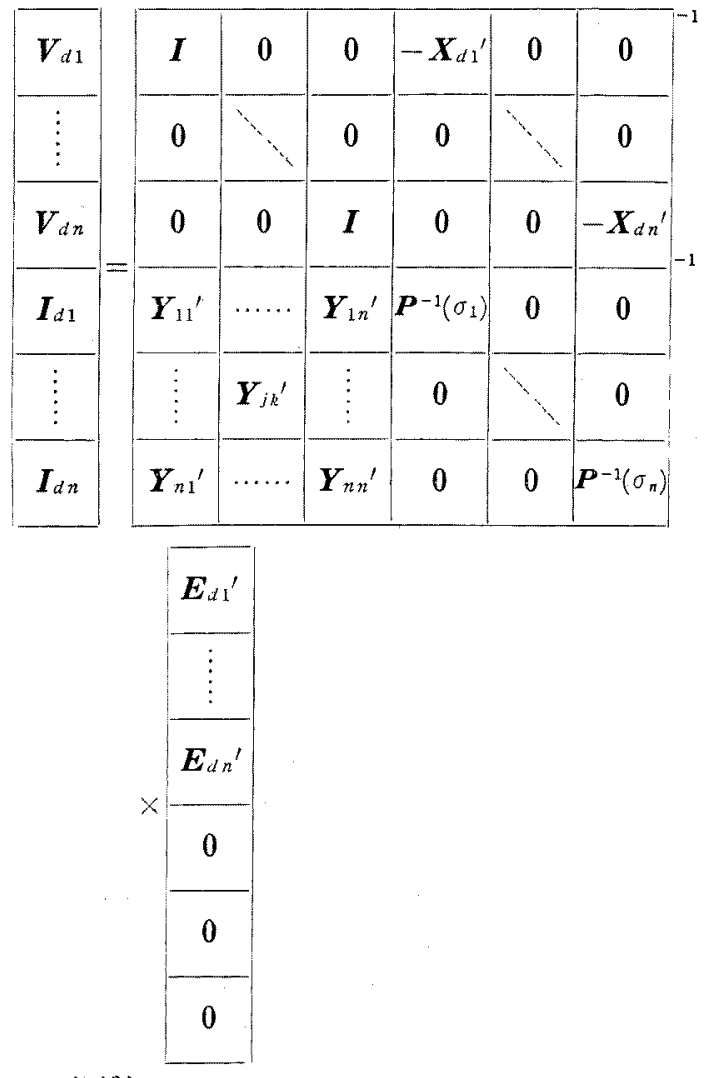

ただし，

$$
\begin{aligned}
& \boldsymbol{X}_{d j^{\prime}}=\left[\begin{array}{cc}
0 & x_{q j^{\prime}} \\
-x_{d j^{\prime}} & 0
\end{array}\right], \quad \boldsymbol{I}=\left[\begin{array}{ll}
1 & 0 \\
0 & 1
\end{array}\right] \\
& \boldsymbol{E}_{d j^{\prime}}=\left[\begin{array}{l}
E_{d j^{\prime}} \\
E_{q j^{\prime}}
\end{array}\right]
\end{aligned}
$$

\section{3. 記号の説明}

$d, q ; D, Q:$ 同期㙨の直軸，横軸方上び共通 基华軸， $\omega_{0}, \omega$ : 同期角速度, 角速度の瞬時值 $\delta: d, q$ 軸之 $D, Q$ 軸の相差角, $x_{d}, x_{d^{\prime}}, x_{d^{\prime \prime}}$ $x_{q}, x_{q}{ }^{\prime}, x_{q}{ }^{\prime \prime}$ : 同期機少了クタンス, $E_{d^{\prime}}{ }^{\prime}, E_{q}{ }^{\prime}$ $E_{f d}$ : 同期機過渡内部誘起電压, 励磁電压, $T_{d^{\prime}}, T_{d}{ }^{\prime \prime}, T_{q}{ }^{\prime}, T_{q}^{\prime \prime}$ ：同期機の時定数， $\boldsymbol{V}_{d}$, $\boldsymbol{I}_{d}, \boldsymbol{V}_{D}, \boldsymbol{I}_{D}: d, q$ 軸および $D, Q$ 軸てて表わ した電圧，電流ベクトル， $M\left(=J / \omega_{0}\right)$ ：慣性 定数, $P_{s}, P_{a s}, P_{t}-\Delta P_{t}$ : 同期, 非同期出力 およびタービン出力, $K, K_{s}, K_{f}, T_{1}, T_{2}, T_{s}$ AVR 定数, $V_{R}$ : AVR 基準笔圧, $K_{\theta}, T_{\theta}$, $T_{h}$ : ガバナ定数,,$x_{e}$ : 外部リアクタンス, $P_{d}, b$ : 制動保数, 脈動係数, $P_{m}, P_{r}$ : 同期出 力およびリラクタンス出力の波高値， $V$ : 無 限大母線の霓圧, $t:$ 時間, $p(=d / d t)$ : 微分 演算子

な招，添字 $j$ は第 $j$ 同期機を表わす。 